\title{
Prevention Effect of Prunus persica Flos Extract from Reactive Oxygen Species Generation and Matrix Metalloproteinases Production Induced by UVB Irradiation in Human Skin Cells
}

\author{
Chung Shil Kwak*, Jiwon Yang \\ Institute on Aging, College of Medicine, Seoul National University, Seoul, Korea
} \author{
Korea \\ Tel.: +82 27408506 \\ Fax: +82 27420626 \\ Email:kwakcs@snu.ac.kr \\ Received April 26, 2016 \\ Revised June 8, 2016 \\ Accepted June 9, 2016 \\ Published June 30, 2016
}

*Corresponding author: Chung Shil Kwak, Institute on Aging, College of Medicine, Seoul National University, 103 Daehak-ro, Jongno-gu, Seoul 03080,

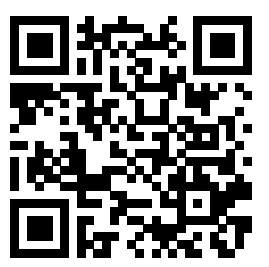

\begin{abstract}
Purpose: Prunus persica Flos (PPF, peach flowers) extracts were reported to have anti-oxidant and anti-inflammatory activities. In this study, we investigated whether PPF extracts prevent the human skin cells from oxidative stress and matrix metalloproteinases (MMPs) induced by UVB irradiation which ultimately leads to photoaging, or not. Methods: Ethanol extract (Et) of PPF and its dichloromethane (DM), ethylacetate (EA), and $\mathrm{n}$-butanol (Bt) fractions were pretreated in UVB-irradiated $\left(75 \mathrm{~mJ} / \mathrm{cm}^{2}\right)$ human keratinocytes (HaCaT) or human dermal fibroblasts (HDF). Cellular reactive oxygen species (ROS) generation was measured using DCF-DA assay, and mRNA expression and production of MMPs were measured by real-time PCR and Western blotting, respectively. Results: The treatment of Et, DM, EA, and Bt significantly inhibited UVB-induced ROS generation and MMP-1 production in HaCaT cells. The treatments of EA and Bt significantly decreased not only the mRNA expression of $M M P-1, M M P-$ 3 , and $M M P-9$ but also the protein production of MMP-1 and MMP-3 in HDF cells, while they increased the expression of type-1 procollagen in mRNA and protein levels. Et and DM significantly inhibited only MMP-1 and MMP-3 production without an preventive effect on type-1 procollagen production in UVB-irradiated HDF cells. Conclusion: The treatments with EA and Bt fractions from PPF extract protected human skin cells from UVB-induced oxidative stress and collagen loss. These findings suggest that EA and Bt fractions from PPF extract have the potential of natural resource for a skin anti-photoaging product in the food and cosmetic industry.
\end{abstract}

Keywords: Prunus persica Flos, Reactive oxygen species, Matrix metalloproteinases, Type-1 procollagen, Ultraviolet B

\section{Introduction}

우리나라 국민의 평균수명이 매우 빠르게 증가함에 따라 노년기가 차지하는 기간이 점차 길어지고 있다. 따라서, 노 인성 만성질환의 발병률이 증가할 뿐 아니라, 신체 조직들의 기능이 저하함에 따라 노년기 삶의 질과 생에 대한 만족감이 크게 감소한다. 이에, 각 분야 연구자들은 노화에 따른 신체 조직들의 기능저하를 지연시키는 다양한 방법을 찾고자 많은 노력을 하고 있다.
피부상태는 전신적인 건강상태 및 노화의 정도를 잘 반영 한다. 인간의 피부세포는 나이가 들어감에 따라 피부두께가 얇아지고, 기미, 검버섯 등이 증가하며, 건조해지고 탄력이 줄어들면서 주름이 생긴다. 피부노화는 크게 내인성 노화와 물리적 자극이나 자외선, xenobiotics와 같은 외적인 요인에 의한 외인성 노화로 나눌 수 있으나 대부분은 동시에 복합적으 로 작용한다. 특히, 자외선에 의한 외인성 피부노화를 피부 광 노화라 한다. 피부노화는 표피, 진피, 피하지방, 세포외기질 등 에서 나타나는 여러 변화들이 복합적으로 작용한 결과이지만 
피부노화의 주요 현상인 색소침착, 주름생성, 건조 등의 작용 기전에는 산화적 스트레스와 염증성 물질의 증가가 관련되 어 있다고 알려져 있다(Baumann, 2007; Kim et al,, 2011; Chiang et al,, 2012). 따라서, 항산화효과나 항염증효과가 있는 물질은 노화와 함께 증가하는 멜라닌 색소의 생성과 콜라 겐의 감소 등을 억제함으로써 피부 광노화를 억제할 수 있을 것으로 기대되고 있다.

자외선(UV)은 파장에 따라 UVA (400-320 nm), UVB (320-290 nm) 그리고 UVC (290-200 nm)로 나뉜다. UVC 는 오존층에서 대부분 흡수되어 사람에게까지 도달하지 는 않으며 UVA는 사람에게 도달하는 전체 UV의 $95 \%$ 에 해 당하는 양으로 사람피부에서 산화적 스트레스를 초래한다 (Fernández-Garcia, 2014). UVA는 활성산소(ROS)의 생성 을 유도하고, 증가한 ROS는 피부세포의 DNA, 단백질, 지질 등을 공격하여 간접적으로 피부손상을 초래하는 반면, $\mathrm{UVB}$ 는 $\mathrm{ROS}$ 와 염증성 매개물질들의 생성을 증가시켜 일광성 화상을 초래할 뿐 아니라, 피부세포의 $\mathrm{DNA}$ 를 직접적으로 공격하여 피부암을 유발할 수 있기 때문에 가장 위험한 것으로 간주되고 있다(Kim et al., 2015a; Debacq-Chainiaux et al., 2012).

피부노화에서 공통적으로 나타나는 주름은 진피층의 세포 외기질의 손상이 가장 큰 요인으로 알려져 있다. 세포외기질 은 콜라겐 1형, 3형, 5형, 7형과 엘라스틴, proteoglycans, fibronectin 등으로 구성되어 있는데 그 중 콜라겐 1형이 대 부분을 차지한다(Kim et al., 2015b). UVB는 복잡한 신호전 달을 통하여 이들 세포외기질의 구성 단백질들을 분해시키는 효소인 matrix metalloproteinases (MMPs)의 생성을 증가 시킴으로써 세포외기질의 분해를 유도하는 것으로 알려져 있 다(Kim et al., 2014; Kim et al., 2011). MMPs는 아연 의 존적인 단백질 분해효소로 염증, 종양전이, 피부노화 등 여 러 과정에서 중요한 역할을 한다(Kim et al., 2011; Hwang et al., 2014). 사람 피부에는 19종의 MMP가 존재하는데 그 중 $\mathrm{MMP}-1, \mathrm{MMP}-3, \mathrm{MMP}-9$ 만 $\mathrm{UV}$ 에 의하여 증가한다 (Quan et al., 2009). 특히, MMP-1은 세포 사이에 존재하 는 주요 콜라겐 분해효소로 피부에 가장 많이 존재하는 1 형과 3 형의 섬유성 콜라겐을 분해하기 때문에 그 영향력이 가장 크 다고 볼 수 있다. MMP-1에 의하여 부분적으로 절단된 콜라겐 은 이어서 $\mathrm{MMP}-3$ 와 $\mathrm{MMP}-9$ 에 의하여 더 작게 분해된다. 따 라서, MMP에 의한 콜라겐의 파괴가 피부 광노화에서 나타나 는 결합조직 손상의 주된 요인으로 알려져 있다(Quan et al., 2009). 한편, 콜라겐 1형은 섬유아세포에서 procollagen 형 태로 합성되어 세포외기질로 분비되기 때문에(Hong et al., 2015; Hwang et al., 2014) 피부세포에서 콜라겐 합성을 촉 진하거나 $\mathrm{MMP}$ 합성이나 활성을 억제시키는 물질은 효과적으로 피부 광노화를 예방할 수 있을 것으로 기대된다.
우리나라에서는 복숭아꽃(Prunus persica Flos)을 복사꽃 이라고도 하며 건조시켜 차로 즐겨 마셨다. 복숭아꽃의 성분 은 정확히 밝혀지지 않았지만 민간요법으로 얼굴에 난 부스 럼이나 습진을 치료하는데 사용하였으며(Lee \& An, 2010), 장운동을 촉진시켜 변비를 해소하고 이뇨제로 이용되었다는 보고가 있다(Han et al., 2015). 또한, Heo et al. (2001)은 동물실험 결과 복숭아꽃 에탄올 추출물이 자외선 $\mathrm{B}$ 와 $\mathrm{C}$ 에 의 한 DNA 손상과 피부종양을 억제하는 효과가 있었는데 그것 은 우수한 항산화효과 때문이라 하였고, Li \& Wang (2011) 도 복숭아꽃 메탄올 추출물은 항산화활성이 우수하였고 라 디칼에 의해 유도되는 DNA 및 단백질의 손상으로부터 보호 하는 효과가 있었다고 하였다. 복숭아꽃에는 플라보노이드 에 속하는 kaempferol과 그 배당체, albamyricetin 등의 성 분들이 함유되어 있고, kaempferol의 경우 지질과산화와 콜 레스테롤 억제효과가 있으며, 항산화효과가 높다고 알려져 있다(Li \& Wang, 2011; Liang et al., 1999). 최근 복숭아 꽃 아세톤 추출물로부터 얻은 일부 분획이 항산화효과가 뛰 어났으며 LPS를 투여한 RAW 264.7 세포에서 산화질소 및 proinflammatory cytokines의 생성을 매우 효과적으로 억 제하였다고 보고되었다(Lee \& An, 2012).

본 연구팀은 이전의 연구에서 복숭아꽃 에탄올 추출물은 LPS를 투여한 RAW 264.7 세포에서 $\mathrm{iNOS}$ 와 COX-2의 합 성을 억제시켜 산화질소와 $\mathrm{PGE}_{2}$ 의 생성을 억제시켰으며, 에 탄올 추출물로부터 얻은 디클로로메탄, 에틸아세테이트, 부 탄올 분획이 폴리페놀 및 플라보노이드 함량이 높고 항산화 효과가 특히 우수하였으며, 특히 에틸아세테이트와 디클로로 메탄 분획은 LPS를 투여한 RAW 264.7 세포에서 산화질소 및 $\mathrm{PGE}, \mathrm{IL}-6, \mathrm{TNF}-\alpha$ 생성을 모두 효과적으로 억제하였 다는 결과를 보고한 바 있다(Kwak \& Choi, 2015).

따라서, 본 연구에서는 항산화효과와 항염증효과가 우수하 였던 복숭아꽃의 에탄올 추출물과 디클로로메탄, 에틸아세테 이트, 부탄올 분획물을 이용하여 인간 피부각질세포 $(\mathrm{HaCaT})$ 와 인간 피부섬유아세포(HDF)에서 UVB 조사에 의하여 나 타나는 ROS와 MMPs의 생성 증가 및 type-1 procollagen 생성 감소 등 피부 광노화를 유도하는 생화학적 특성에 어떠 한 영향을 미치는지 연구하고자 하였다.

\section{Methods}

\section{1. 시료의 구입, 전처리 및 추출과 분획}

시료는 전라남도 화순에서 재배하여 증기로 쪄서 건조시킨 복숭아꽃차를 구입하여 사용하였다. 구입한 복숭아꽃차는 실험 실에서 동결건조기(Samwon, Korea)에서 감압 하에 1 일간 더 


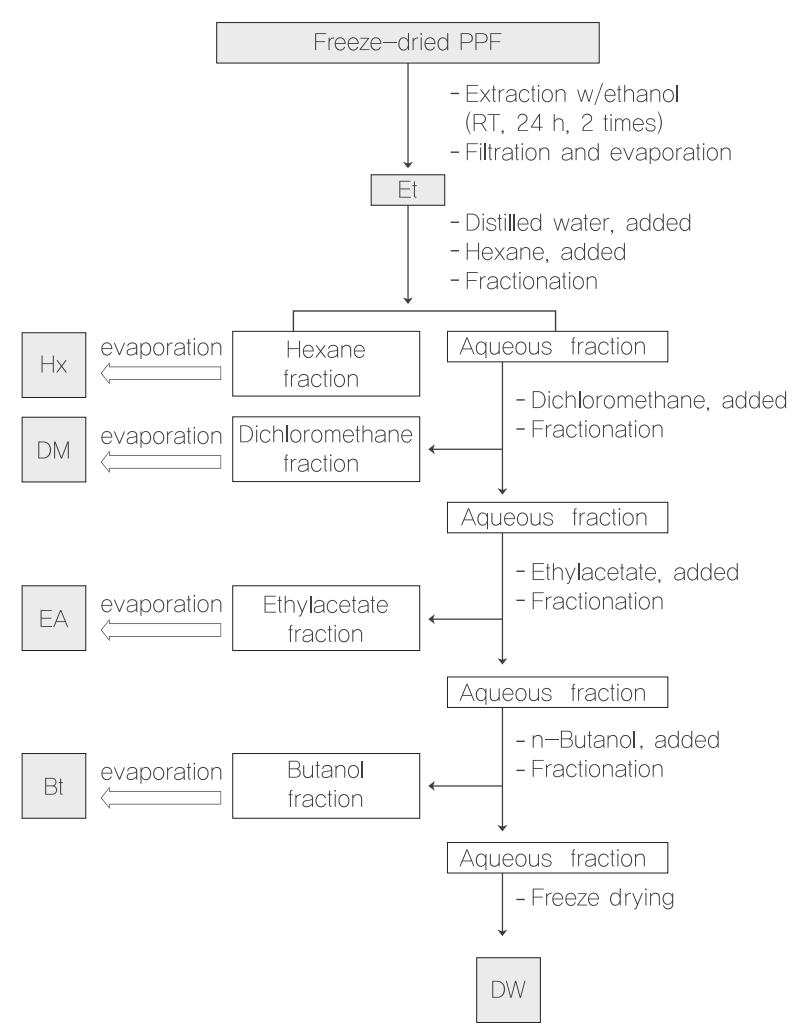

Figure 1. Procedure for extraction and sequential fractionation from Prunus persica Flos (PPF).

건조시킨 후 가정용 식품분쇄기를 이용하여 곱게 분쇄하여 냉동 실에 보관하였다. 복숭아꽃 건조시료로부터 에탄올 추출 시료 및 분획 시료를 얻는 과정은 Figure 1과 같다. 복숭아꽃 건조시 료 일정량에 20 배 부피의 에탄올(Duksan, Korea)을 플라스크 에 붓고 입구를 봉한 다음 stirring 하면서 실온에서 $24 \mathrm{~h}$ 동 안 2회 반복 추출하였다. 추출용액을 모아 Whatman 여과지 (No.2, GE Healthcare Life Sciences, UK)로 거른 후 여과액 을 rotary vacuum evaporator (EYELA, Japan)로 $30^{\circ} \mathrm{C}$, 감 압 하에 에탄올을 증발시켜 농축액을 얻었다. 에탄올 추출 농축 액 $(\mathrm{Et})$ 에 적당량의 물을 섞어 분산시킨 후 극성의 정도에 따라 핵산 $(\mathrm{Hx})$, 디클로로메탄 $(\mathrm{DM})$, 에틸아세테이트 $(\mathrm{EA}), \mathrm{n}$-부탄올 $(\mathrm{Bt})$ 및 물 $(\mathrm{DW})$ 분획의 순으로 분액 깔대기를 이용하여 순차적 으로 용매분획을 시행한 다음 각 분획물을 rotary evaporator 로 농축한 후 dimethyl sulfoxide (DMSO)에 $50 \mathrm{mg} / \mathrm{mL}$ 농도로 녹여 $-20^{\circ} \mathrm{C}$ 에 냉동보관하였다가 실험에 사용하였다.

\section{2. 세포배양 및 시료처리}

$\mathrm{HaCaT}$ 과 $\mathrm{HDF}$ 세포는 서울대학교 의과대학 피부과 실험 연구실에서 분양 받았다. 세포는 $100 \mathrm{~mm}$ 세포배양접시에서 $10 \% \mathrm{FBS}(\mathrm{v} / \mathrm{v}), 1 \mathrm{mM}$ glutamine, $100 \mathrm{units} / \mathrm{mL}$ penicillin과
$50 \mu \mathrm{g} / \mathrm{mL}$ streptomycin을 함유하는 dulbecco's modified eagle medium (DMEM; Welgene Inc., Korea)을 이용하 여 $37^{\circ} \mathrm{C}, 5 \% \mathrm{CO}_{2}$ 세포배양기에서 계대배양하였다. $\mathrm{DMSO}$ 에 녹 인 각 농축시료는 $0.2 \mu \mathrm{m}$ syringe filter로 여과하여 멸균한 다 음 $\mathrm{DMEM}$ 배지로 희석하여 세포에 다양한 농도로 처리하였다.

\section{UVB 조사}

세포 배양액을 제거한 후 $\mathrm{PBS}$ 로 세척하고 다시 세포를 살 짝 덮을 만큼의 phosphate buffered saline (PBS)를 넣은 후 UV 조사기 안에 넣고 275-380 nm (peak: 290-320 nm) 파장의 빛을 발산하는 fluorescent sun lamp (Philips TL 20W/12 RS, Philips, Netherland)를 이용하여 UVB를 조사 하였다. 이 때 UVC를 제거하기 위하여 TA 401/407 Kodacel filter (Kodak, USA)를 사용하였고, UV의 강도는 UV meter (UVP, USA)로 측정하였다.

\section{4. 세포 생존율 측정}

복숭아꽃 추출시료와 UVB에 대한 세포독성 실험은 3[4,5-dimethylthiazol-2-yl]-2,5-diphenyltetrazolium bromide (MTT)를 이용한 방법(Mosmann, 1983)으로 측정하 였다. HaCaT 또는 HDF 세포를 96-well plate에 일정 수만 큼 심고 $24 \mathrm{~h}$ 배양 한 다음 배양액을 무혈청 DMEM으로 교 환하면서 각 추출시료를 여러 농도로 처리하였다. 다시 $24 \mathrm{~h}$ 또는 $48 \mathrm{~h}$ 배양 후에 배양액을 제거하고 $\mathrm{PBS}$ 로 세척하고 각 well에 MTT 용액을 첨가한 후 $37^{\circ} \mathrm{C}$ 에서 3-4 h 배양한 다 음 용액을 제거하고 $200 \mu \mathrm{L}$ 의 $\mathrm{DMSO}$ 를 첨가하여 formazan crystals을 용해시킨 다음 ELISA reader를 이용하여 $540 \mathrm{~nm}$ 에서 흡광도를 측정하였다.

\section{5. 세포에서의 ROS 생성량 측정}

$\mathrm{HaCaT}$ 세포에서의 ROS생성량은 Yoo et al. (2014)의 방 법에 따라 측정하였다. $\mathrm{HaCaT}$ 세포를 $10 \% \mathrm{FBS}$ 를 함유하는 DMEM에서 배양하여 24-well plate에 일정하게 심고 $24 \mathrm{~h}$ 배 양 후 각 시료를 여러 농도로 함유하는 무혈청 DMEM 배양액 으로 갈아 주었다. 다시 $24 \mathrm{~h}$ 배양 후 배양액을 제거하고 $40 \mu$ M 2'-7'-dichlorofluorescin diacetate (DCF-DA)를 함유 하는 phenol red-free media으로 $30 \mathrm{~min}$ 동안 염색하고 PBS 로 2 회 세척한 후 UVB $\left(75 \mathrm{~mJ} / \mathrm{cm}^{2}\right)$ 를 조사한 다음 $30 \mathrm{~min}-1$ $\mathrm{h}$ 동안 세포배양기에서 배양하였다. 각 well의 상층액을 따서 ELISA reader가 부착된 fluorometer (TECAN, Switzerland) 를 이용하여 excitation $485 \mathrm{~nm}$, emission $530 \mathrm{~nm}$ 에서 형광 도를 측정하여 대조군에 대한 비율을 구하였다. 동일한 조건에 서 MTT 방법으로 세포 생존율을 측정하여 보정하였다. 


\section{Western blot}

세포에서 단백질을 추출하기 위하여 배양액을 제거하고 차 가운 $\mathrm{PBS}(\mathrm{pH}$ 7.4)로 2회 세척한 다음 protease inhibitor (Roche, Germany)를 포함하는 RIPA 버퍼(Sigma-Aldrich, $\mathrm{USA}$ 를 넣고 얼음 위에 $20 \mathrm{~min}$ 동안 두었다가 $4^{\circ} \mathrm{C}, 10,000 \mathrm{~g}$ 에서 $15 \mathrm{~min}$ 원심분리하여 상층액을 모은 후 Bradford (1976) 방법으로 단백질 농도를 측정하였다. 모든 시료의 단백질 농도 가 동일하도록 조정한 후 $5 \mathrm{X}$ sodium dodecyl sulfate (SDS) sample buffer (Sigma-Aldrich)를 가하고 $100^{\circ} \mathrm{C}$ 에서 5 min 끓였다. Mini-PROTEIN system (BIO-Rad, USA)를 이용하여 8-10\% SDS polyacrylamide gel에 동량의 단백질 시료를 loading하고 전기영동을 시행하였으며 이어서 Amersham Hybond P 0.45 PVDF membranes (GE Healthcare Life Sciences, UK)에 transfer시켰다. Membrane 을 $0.1 \%$ Tween-20을 함유하는 Tris-buffered saline (TBST, $\mathrm{pH}$ 8.0)에 탈지분유를 $5 \%$ 가 되도록 용해시킨 blocking solution에 넣어 실온에서 $1 \mathrm{~h}$ 동안 blocking 한 후 antiMMP-1 및 anti-type-1 procollagen (자체 제작), antiMMP-3 (Santa Cruz Biotechnology, USA) 또는 anti$\beta$-actin (Sigma-Aldrich)을 blocking solution으로 희석 한 용액에 넣고 $4^{\circ} \mathrm{C}$ 에서 $18 \mathrm{~h}$ 두었다. Membrane을 TBST 로 세척 후 실온에서 2차 항체로 MMP-1은 horseradish peroxidase-conjugated anti-rabbit IgG, MMP-3 는 anti-goat (Santa Cruz Biotechnology), type-1 procollagen과 $\beta$-actin에 대하여는 anti-mouse (SigmaAldrich)를 사용하여 $2 \mathrm{~h}$ 동안 노출시킨 다음 세척하고 ECL solution (Pierce, USA)을 뿌려 LAS-4000 Luminescent Image Analyzer (Fujifilm, Japan)을 이용하여 밴드를 확인 하고 정량하였다.

\section{Quantitative real-time PCR}

$\mathrm{HDF}$ 에 추출 시료를 농도별로 $24 \mathrm{~h}$ 전처리한 후 UVB $(75 \mathrm{~mJ} /$ $\mathrm{cm}^{2}$ )를 조사하고 $24 \mathrm{~h}$ 배양하였다. 배양액을 제거하고 easyspin Total RNA extraction kit (iNtRON Biotechnology,
Korea)을 이용하여 세포에서 RNA를 추출하였고 Nanodrop 1000 spectrophotometer (Thermo Scientific, USA)를 이 용하여 RNA양을 측정하였다. 일정량의 RNA를 취한 다 음 Primescript Reverse Transcriptase (Takara, Japan) 를 사용하여 $\mathrm{cDNA}$ 를 합성하였다. 이어서 유전자들의 발현 을 측정하기 위하여 SYBR Green Mastermix (Faststart Universial SYBR Green Mastermix, Roche, USA)와 각각 의 primer를 이용하여 real-time PCR machine (Applied Biosystems 7500 Real Time PCR systems, Thermo Fisher Scientific, USA)에서 qRT-PCR을 진행하였으며 $\mathrm{PCR}$ 과정은 $40 \mathrm{cycle}$ 수행하였다. 모든 유전자의 $\mathrm{PCR}$ 산물 의 크기는 $100 \mathrm{bp}$ 내외로 하였고, 각각의 유전자에 대한 $\mathrm{PCR}$ primer의 염기서열은 Table 1 과 같다. Real-time PCR 반 응액은 총 $20 \mu \mathrm{L}$ 로 cDNA $1 \mu \mathrm{L}$, SYBR Green master mix $10 \mu \mathrm{L}$, forward reverse primer $1 \mu \mathrm{L}$ (10 pmole), 증류수 $7 \mu \mathrm{L}$ 였으며 모든 유전자에 대하여 $\mathrm{PCR}$ 증폭 단계는 다음과 같다. Hot start를 위해 $95^{\circ} \mathrm{C}$ 에서 $10 \mathrm{~min}, 95^{\circ} \mathrm{C}$ 에서 $15 \mathrm{~s}, 60^{\circ}$ $\mathrm{C}$ 에서 1 min으로 40 cycle을 반복하고, melting curve에서 $95^{\circ} \mathrm{C}$ 에서 $15 \mathrm{~s}, 60^{\circ} \mathrm{C}$ 에서 $1 \mathrm{~min}, 95^{\circ} \mathrm{C}$ 에서 $30 \mathrm{~s}$ 로 하였다. 기준 유전자는 UVB에 의하여 영향받지 않는 $36 \mathrm{~B} 4$ 를 사용하 였다. 결과의 분석은 Applied Biosystems (USA)에서 제공 하는 7500 software (ver. 2.0.6)를 이용하여 분석하였다.

\section{8. 통계분석}

모든 실험결과는 3 회 이상 반복하여 평균 \pm 표준편차로 나 타내었다. 또한, 시료들 간의 실험 측정치를 비교하기 위하여 Statistics Analysis Systems (SAS ver. 9.4; SAS Institute, $\mathrm{USA})$ 을 이용하여 ANOVA-test 실시 후 T-test를 실시하여 $p<.05$ 일 때 대조군에 비하여 각 실험군의 결과가 통계적으로 유의한 지를 평가하였다.

Table 1. List of primers

\begin{tabular}{|c|c|c|}
\hline Gene & Primer & Sequence \\
\hline \multirow{2}{*}{$36 B 4$ (control) } & Forward & 5'-TGG GCT CCA AGC AGA TGC-3' \\
\hline & Reverse & 5'-GGC TCC GCT GGC TCC CAC-3' \\
\hline \multirow{2}{*}{$M M P-1$} & Forward & 5'-ATT CTA CTG ATA TCG GGG CTT TGA-3' \\
\hline & Reverse & 5'-ATG TCC TTG GGG TAT CCG TGT AG-3' \\
\hline \multirow{2}{*}{$M M P-3$} & Forward & 5'-ATT CCA TGG AGC CAG GCT TTC-3' \\
\hline & Reverse & 5'-CAC AGT TGG AGT TTG ACC CAA ATG-3' \\
\hline \multirow{2}{*}{$M M P-9$} & Forward & 5'-TTG ACA GCG ACA AGA AGT GG-3' \\
\hline & Reverse & 5'-GCC ATT CAC GTC GTC CTT AT-3' \\
\hline \multirow{2}{*}{ Procollagen $\alpha 1(\mathrm{I})$} & Forward & 5'-CTC GAG GTG GAC ACC ACC CT-3' \\
\hline & Reverse & 5'-CAG CTG GAT GGC CAC ATC GG-3' \\
\hline
\end{tabular}



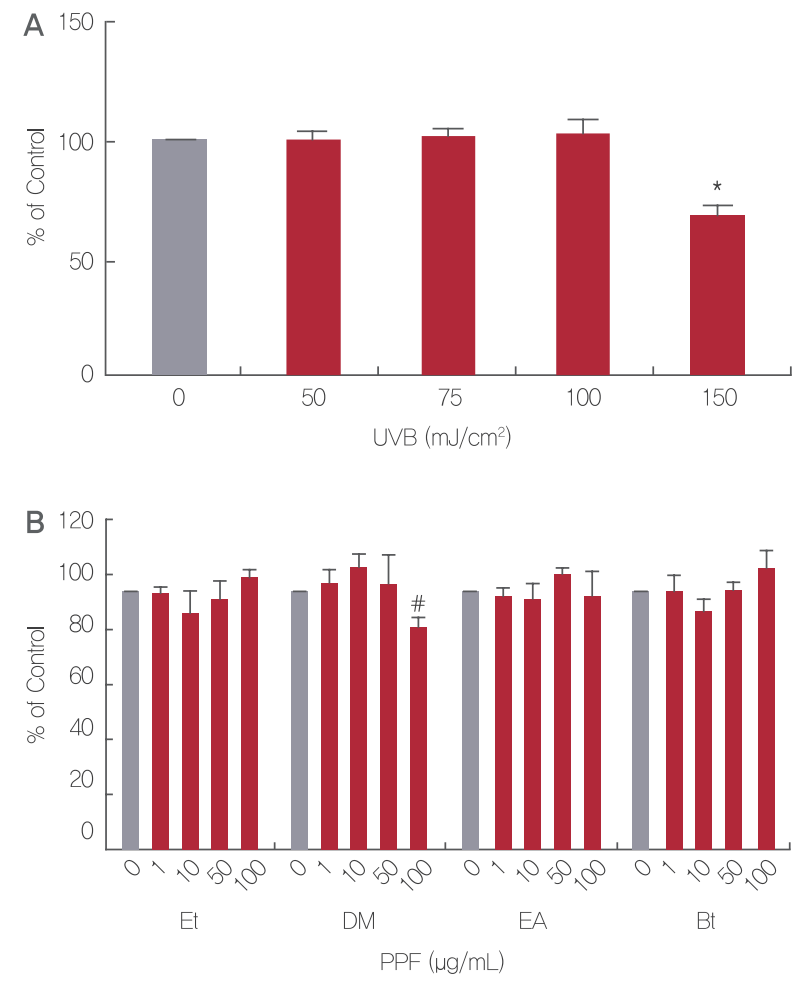

Figure 2. Effect of treatment with PPF extract or UVB on cell viability of $\mathrm{HaCaT}$ cells.

Cell viability was measured at $48 \mathrm{~h}$ after UVB irradiation without extract treatment (A) or $24 \mathrm{~h}$ after treatment with extracts of PPF with different concentrations without UVB irradiation (B). Results are expressed as the mean \pm S.D. of more than three independent experiments. ${ }^{*}$ significantly different from UVB-irradiated control at $p<.05$. \# lower than $90 \%$ of control.

\section{Results}

\section{1. $\mathrm{HaCaT}$ 에서 UVB 조사와 복숭아꽃 추출물의 세포독성}

$\mathrm{HaCaT}$ 에서 UVB 조사 강도에 따른 세포독성을 알아보기 위 하여 UVB를 세포에 $0,50,75,100,150 \mathrm{~mJ} / \mathrm{cm}^{2}$ 로 조사하 고 $48 \mathrm{~h}$ 배양한 후 세포생존율을 측정한 결과 $150 \mathrm{~mJ} / \mathrm{cm}^{2}$ 으 로 조사한 세포의 생존율만 대조군의 $67.8 \%$ 로 크게 감소하 였을 뿐 $100 \mathrm{~mJ} / \mathrm{cm}^{2}$ 이하에서는 세포독성이 보이지 않았다 (Figure 2A). 따라서 본 연구에서는 세포생존에 영향을 주지 않는 범위에서 중간수준인 $75 \mathrm{~mJ} / \mathrm{cm}^{2}$ 로 조사하였다. 또한, 복숭아꽃 추출물 $\mathrm{Et}, \mathrm{DM}, \mathrm{EA}, \mathrm{Bt}$ 를 각각 $1,10,50,100 \mu \mathrm{g} /$ $\mathrm{mL}$ 농도로 처리하고 $24 \mathrm{~h}$ 배양한 후에 세포독성을 측정한 결 과 $100 \mu \mathrm{g} / \mathrm{mL}$ 농도의 $\mathrm{DM}$ 처리군(86.2\%)을 제외하고 모두 세 포 생존율이 대조군의 $90 \%$ 이상을 나타내었다(Figure 2B). 따라서, $\mathrm{HaCaT}$ 에 대하여 DM은 $50 \mu \mathrm{g} / \mathrm{mL}$ 이하, Et, EA, Bt는 $100 \mu \mathrm{g} / \mathrm{mL}$ 이하에서는 세포독성이 없는 것으로 간주하였다.

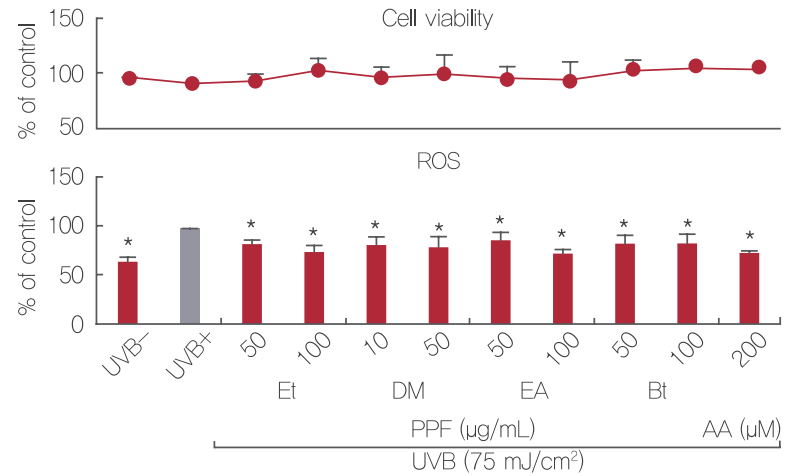

Figure 3. Treatment of PPF extract inhibits UVB-induced ROS generation in $\mathrm{HaCaT}$ cells.

Cells were treated with Et, DM, EA, and Bt of PPF for $24 \mathrm{~h}$ prior to UVB irradiation $\left(75 \mathrm{~mJ} / \mathrm{cm}^{2}\right)$ and after 30 min incubation, the cellular ROS level was measured using DCF-DA. Ascorbic acid (AA) is used as a positive control. Results are expressed as the mean \pm S.D. of more than three independent experiments. ${ }^{*}$ significantly different from UVB-irradiated control at $p<.05$.

\section{2. 복숭이꽃 추출물이 UVB에 의한 ROS 생성을 억제시키는 효과}

$\mathrm{UVB}$ 를 $\mathrm{HaCaT}$ 에 조사하였을 때 세포에서 생성된 ROS는 $\mathrm{UVB}$ 를 조사하지 않은 대조군에 비하여 $54.3 \%$ 증가하였으나 복숭아꽃 추출물 $\mathrm{Et}, \mathrm{DM}, \mathrm{EA}, \mathrm{Bt}$ 를 $24 \mathrm{~h}$ 전처리 했을 때에는 세포독성 없이 $\mathrm{UVB}$ 에 의한 ROS 생성을 억제시켰다( $p<.05$, Figure 3). 특히 Et $(100 \mu \mathrm{g} / \mathrm{mL})$ 와 EA $(100 \mu \mathrm{g} / \mathrm{mL})$ 는 $\mathrm{UVB}$ 에 의한 ROS 생성을 각각 $24.4 \%$ 와 $26.1 \%$ 감소시켰는 데 이는 양성대조시약인 ascorbic acid $(200 \mu \mathrm{M})$ 가 $25.4 \%$ 감소시킨 것과 비교하면 거의 비슷한 효과였다. 따라서, 복숭 아꽃의 $\mathrm{Et}$ 추출물과 $\mathrm{EA}$ 분획은 각질세포에서 UVB에 의한 산 화적 스트레스의 증가를 억제하는 효과가 매우 탁월할 것으로 예측된다.

\section{3. 복숭아꽃 추출물이 HaCaT에서 UVB 조사에 의한 MMP-1 증가에 미치는 영향}

복숭아꽃 추출물의 전처리가 UVB 조사에 의하여 증가하는 것으로 알려진 MMP-1 합성에 미치는 영향을 알아보고자 하였다. 먼저, 동일 조건에서 세포독성이 없는 각 추출물의 농도를 확인하기 위하여 여러 농도로 $\mathrm{HaCaT}$ 에 $24 \mathrm{~h}$ 처리하 고 UVB $\left(75 \mathrm{~mJ} / \mathrm{cm}^{2}\right)$ 를 조사한 후 다시 $48 \mathrm{~h}$ 배양한 다음 세포생존율을 측정하여 적정투여농도를 선정하였다(Figure $4 \mathrm{~A})$. 무독성의 농도로 복숭아꽃 추출물을 $\mathrm{HaCaT}$ 세포에 처리하였을 때 UVB를 조사한 대조군의 $\mathrm{MMP}-1$ 단백질량 에 비하여 Et $(50 \mu \mathrm{g} / \mathrm{mL})$ 는 $37.9 \%, \mathrm{DM}(10 \mu \mathrm{g} / \mathrm{mL})$ 은 $30.9 \%, \mathrm{EA}(50 \mu \mathrm{g} / \mathrm{mL})$ 는 $28.5 \%, \mathrm{Bt}(50 \mu \mathrm{g} / \mathrm{mL})$ 는 $26.6 \%$ 씩 유의하게 $(p<.05)$ 감소시키는 효과를 보였다(Figure $4 \mathrm{~B})$. 

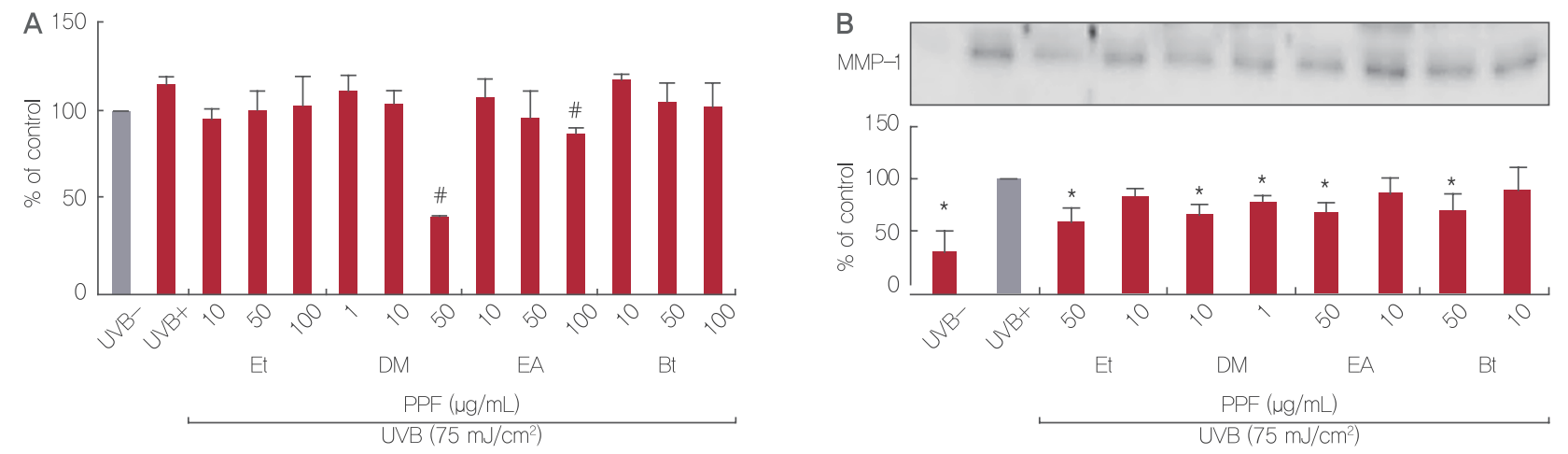

Figure 4. Treatment of PPF extracts inhibits UVB-induced MMP-1 production in HaCaT cells.

Cells were treated with Et, DM, EA, and Bt of PPF for $24 \mathrm{~h}$ prior to UVB irradiation $\left(75 \mathrm{~mJ} / \mathrm{cm}^{2}\right)$ and cell viability was measured after $48 \mathrm{~h}$ incubation (A). MMP-1 released into culture medium was assessed by Western blot analysis and quantified (B). Results are expressed as the mean士S.D. of more than three independent experiments. * significantly different from UVB-irradiated control at $p<.05$. \# lower than $90 \%$ of control.
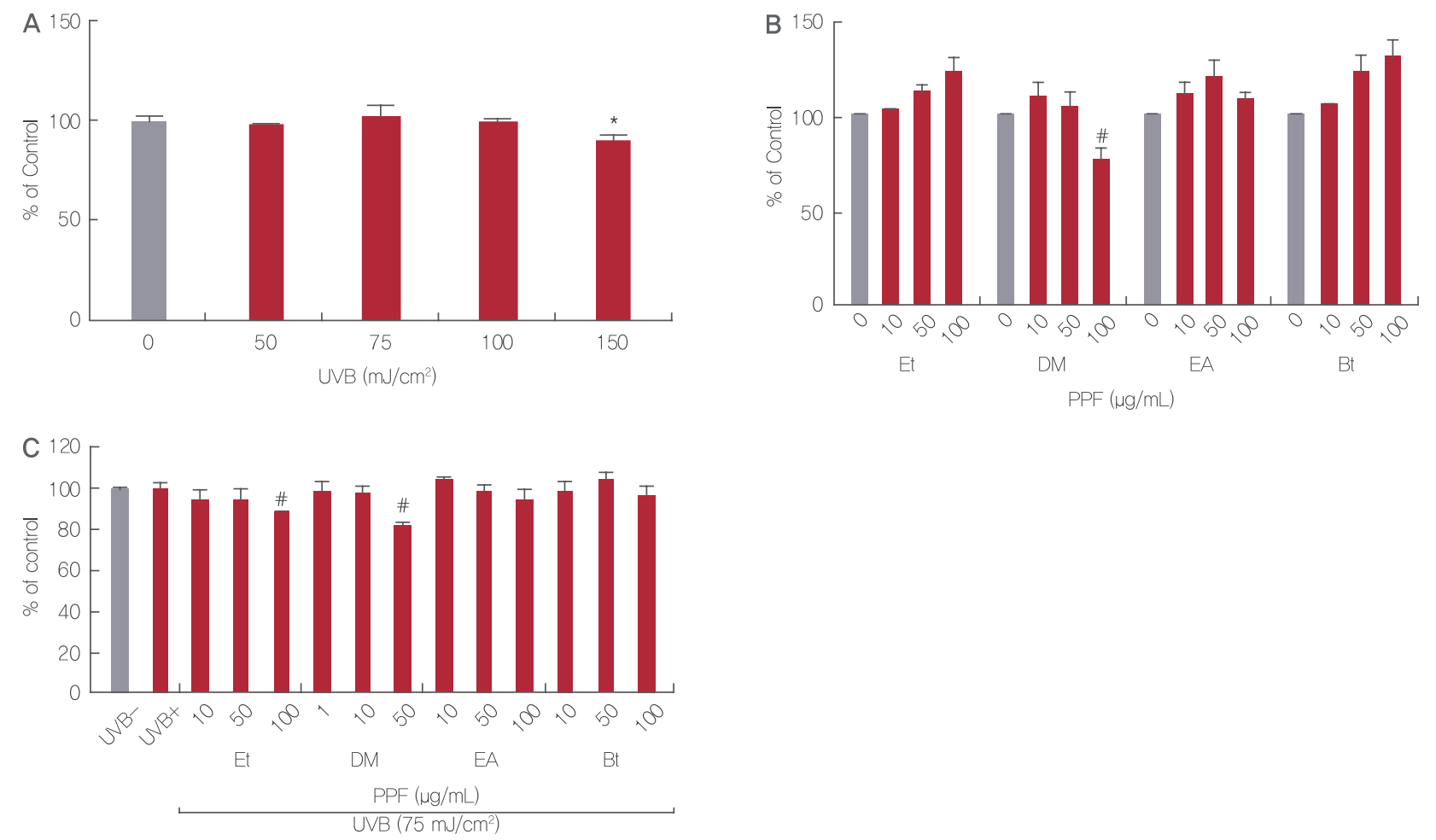

Figure 5. Effect of treatment with PPF extract or UVB on cell viability of HDF cells.

Cell viability was measured at $48 \mathrm{~h}$ after UVB irradiation without extract treatment (A). Cell viability was measured at $24 \mathrm{~h}$ after treatment with extracts of PPF without UVB irradiation (B). Cell viability was measured at $48 \mathrm{~h}$ after UVB irradiation with PPF extracts (C). Results are expressed as the mean \pm S.D. of more than three independent experiments. * significantly different from UVB-irradiated control at $p<.05$. \# lower than $90 \%$ of control.

\section{HDF에서 UVB 조사와 복숭아꽃 추출물의 세포독성}

$\mathrm{HDF}$ 에서 UVB 조사 강도에 따른 세포독성을 알아보기 위 하여 UVB를 세포에 $0,50,75,100,150 \mathrm{~mJ} / \mathrm{cm}^{2}$ 로 조사하고
$48 \mathrm{~h}$ 배양한 후 세포생존율을 측정한 결과 $150 \mathrm{~mJ} / \mathrm{cm}^{2}$ 으로 조 사한 세포의 생존율만 대조군의 $89.6 \%$ 로 감소하였을 뿐 $100 \mathrm{~mJ} / \mathrm{cm}^{2}$ 이하에서는 감소하지 않았다(Figure $5 \mathrm{~A}$ ). 
A
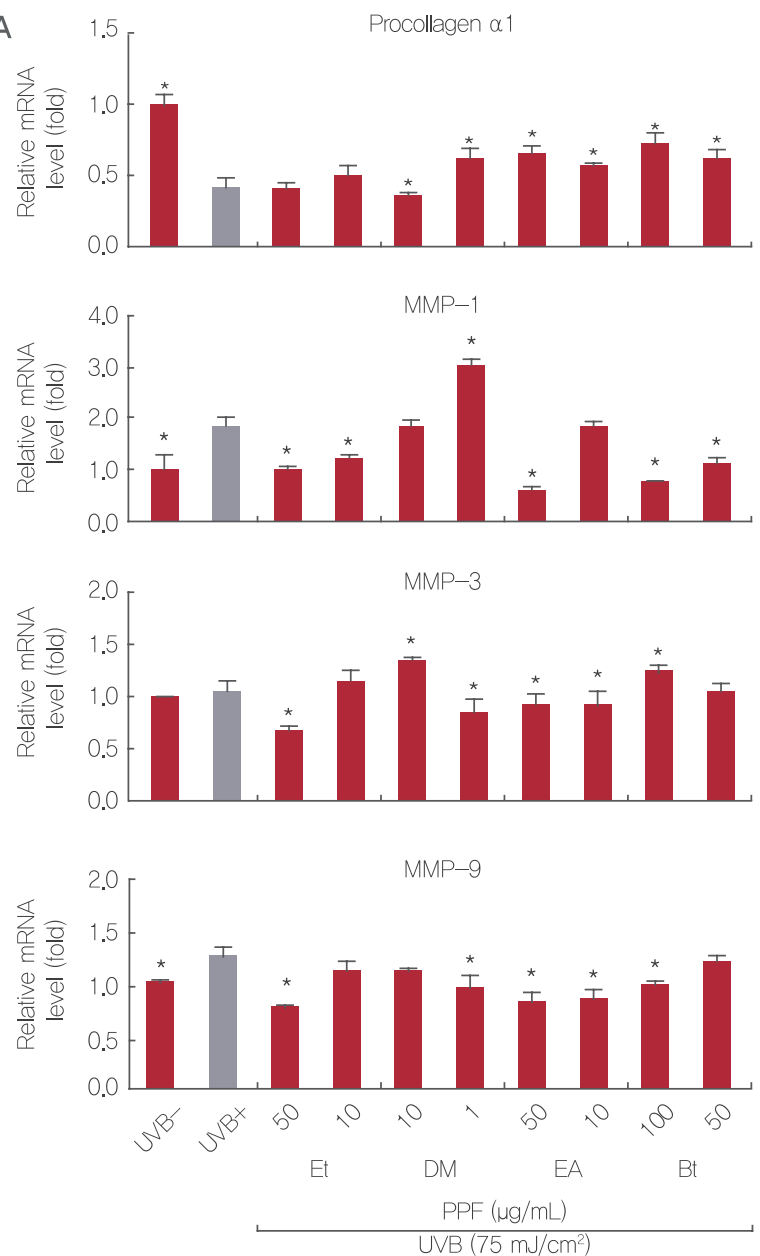
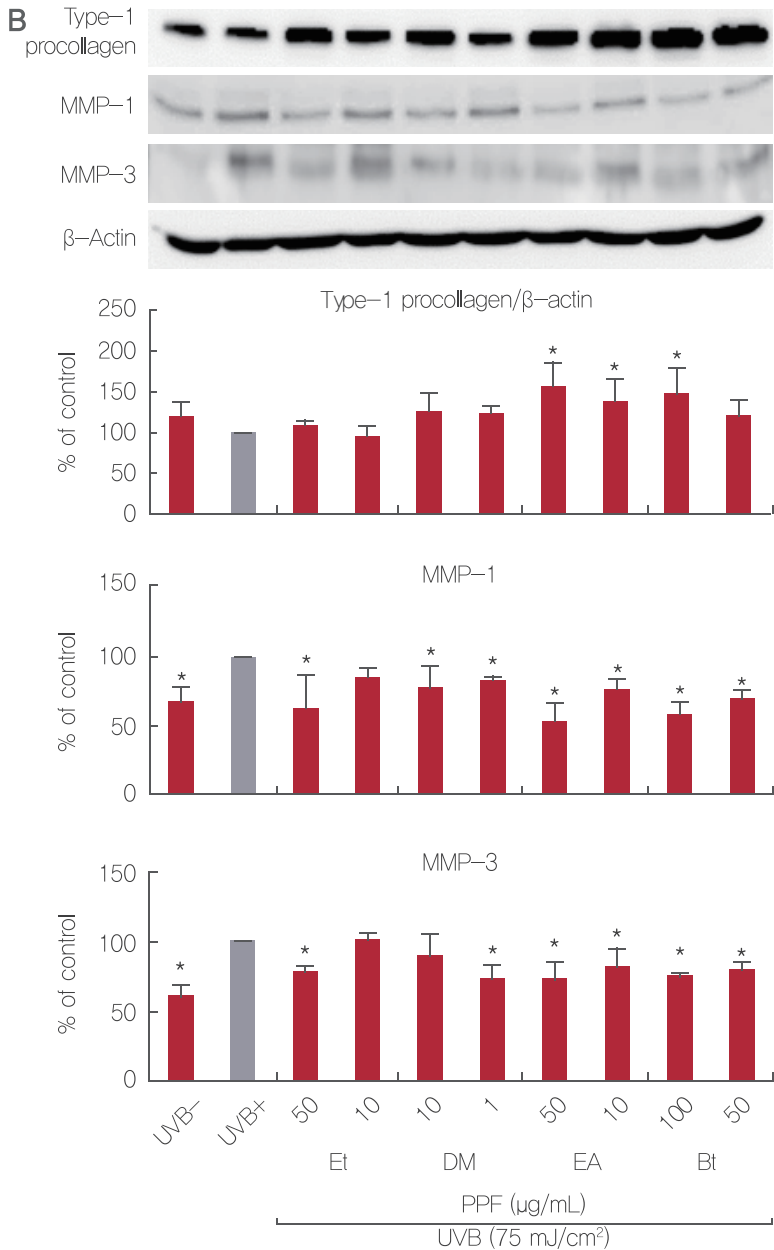

Figure 6. Treatment of PPF extract modulate expression of type-1 procollagen and MMPs in UVB-irradiated HDF cells. Cells were treated with PPF extracts for $24 \mathrm{~h}$ prior to UVB $\left(75 \mathrm{~mJ} / \mathrm{cm}^{2}\right)$ irradiation. mRNA level of type-1 procollagen and MMPs was measured by real-time PCR after $24 \mathrm{~h}$ incubation (A), and their protein levels were measured by Western blotting after $48 \mathrm{~h}$ incubation (B). Results are expressed as the mean \pm S.D. of more than three independent experiments. * significantly different from UVB-irradiated control at $p<.05$.

따라서, $\mathrm{HDF}$ 를 이용한 실험에서도 $\mathrm{HaCaT}$ 실험에서와 동일하 게 $75 \mathrm{~mJ} / \mathrm{cm}^{2}$ 로 조사하였다. 또한, 복숭아꽃 추출물의 $\mathrm{HDF}$ 에 대한 세포독성을 알아보기 위하여 $\mathrm{Et}, \mathrm{DM}, \mathrm{EA}, \mathrm{Bt}$ 를 각 각 $10,50,100 \mu \mathrm{g} / \mathrm{mL}$ 농도로 $24 \mathrm{~h}$ 처리 후 세포독성을 측정 한 결과 $100 \mu \mathrm{g} / \mathrm{mL}$ 농도의 $\mathrm{DM}$ 처리군(77.3\%)을 제외하고는 모두 세포 생존율이 대조군의 $90 \%$ 이상을 나타내었다(Figure $5 \mathrm{~B})$. 또한, 복숭아꽃 추출물을 처리하고 $\mathrm{UVB}$ 를 조사한 다음 $48 \mathrm{~h}$ 후에 세포 생존율을 측정하였을 때 $\mathrm{Et}(100 \mu \mathrm{g} / \mathrm{mL})$ 와 $\mathrm{DM}(50 \mu \mathrm{g} / \mathrm{mL})$ 처리군은 각각 대조군의 $87.8 \%$ 와 $81.3 \%$ 로 감 소하였으나 나머지 군들은 모두 90\% 이상이었다(Figure 5C).

\section{HDF에서 복숭아꽃 추출물이 UVB 조사에 의한 MMPs와} type-1 collagen의 발현 및 단백질량의 변화에 미치는 영향

$\mathrm{HDF}$ 에 UVB $\left(75 \mathrm{~mJ} / \mathrm{cm}^{2}\right)$ 를 조사한 결과 Procollagen $\alpha 1$ 의 mRNA 발현량은 UVB를 조사하지 않은 대조군에 비하여 $41.1 \%$ 로 감소된 반면( $p<.05), M M P-1$ 과 $M M P-9$ 의 $\mathrm{mRNA}$ 발현량은 각각 $84.9 \%$ 와 $25.3 \%$ 증가하였고( $p<.05)$, $M M P-3$ 의 mRNA 발현량은 변하지 않았다. 그러나, 복숭아 꽃 추출물을 전처리한 경우 $\mathrm{DM}, \mathrm{EA}, \mathrm{Bt}$ 는 UVB에 의하여 감 소한 Procollagen $\alpha 1 \mathrm{mRNA}$ 발현량을 유의하게 증가시킨 반면( $p<.05), \mathrm{Et}, \mathrm{EA}, \mathrm{Bt}$ 는 $\mathrm{UVB}$ 에 의하여 증가한 $M M P-1$ 의 $\mathrm{mRNA}$ 발현량을 유의하게 감소시켰다 $(p<.05)$. 특히, $\mathrm{Et}$ $(50 \mu \mathrm{g} / \mathrm{mL})$ 와 $\mathrm{EA}(50 \mu \mathrm{g} / \mathrm{mL})$ 는 $M M P-1, M M P-3, M M P-9$ 의 $\mathrm{mRNA}$ 를 모두 유의하게 감소시켰다( $p<.05$, Figure $6 \mathrm{~A})$.

한편, $\mathrm{UVB}$ 를 조사한 $\mathrm{HDF}$ 에서 복숭아꽃 추출물의 전처리 가 type-1 procollagen과 MMPs 단백질량에 미치는 영향은 Figure $6 \mathrm{~B}$ 와 같다. $\mathrm{EA}$ 와 $\mathrm{Bt}$ 분획은 $\mathrm{UVB}$ 조사에 의하여 감 소한 type-1 procollagen의 단백질량을 유의하게 $(p<.05)$ 
증가시키는 효과를 보였으며, Et, DM, EA, Bt 등 모든 추출 물이 UVB 조사에 의하여 증가한 MMP- 1 와 MMP- 3 의 단백 질량을 유의하게 감소시켰다( $p$ 〈.05). 따라서, $\mathrm{HDF}$ 에 $\mathrm{UVB}$ 를 조사하기 전에 $\mathrm{EA}$ 와 $\mathrm{Bt}$ 분획을 처리하면 type- 1 procollagen 의 양은 증가되는 동시에 $\mathrm{MMP}-1$ 와 $\mathrm{MMP}-3$ 의 양은 감소 되어 UVB에 의한 콜라겐의 감소와 손상을 억제시킬 것으로 기대된다.

\section{Discussion}

햇빛 중의 자외선은 피부 손상을 초래하는 주요 환경요인 이다. 자외선과 피부 구성물질 간의 상호작용이 일어나 광노 화라고 하는 변화를 가져오게 하는데 피부에 만성적으로 자 외선을 쪼이면 $\mathrm{ROS}$ 와 $\mathrm{MMP}$ 의 생성이 증가한다. ROS는 직 접적으로 피부세포의 DNA와 RNA 손상을 일으키는 동시에 지질과산화 및 단백질 산화를 초래하여 세포사멸이나 병변을 가져오게 하고, activator protein (AP)-1, nuclear factor $(\mathrm{NF})-\kappa \mathrm{B}$ 와 같은 전사인자의 활성화를 통하여 유전자발현 조절이나 신호전달 경로에서 second messenger로 작용하여 항산화 효소, 콜라겐 분해 효소 및 콜라겐 합성효소, 염증성 사이토카인들의 생성에 영향을 미치는 것으로 보고되어 피부 노화의 주범으로 알려져 있다(Kim et al., 2014; Kim et al., 2015a; Song \& Gao, 2014).

피부에는 항산화 시스템이 존재하여 UV를 비롯한 어떤 자 극에 의하여 ROS 생성이 증가한 경우 빠르게 제거하는 기전 이 작동하고 있지만 반복적이거나 너무 강한 UV를 받게 되면 피부손상을 피할 수가 없다. 따라서, UV에 의한 피부 광노화 를 방지하기 위해서는 ROS의 생성을 지속적으로 억제시키거 나 빠르게 제거하는 방법을 찾는 노력이 지속되고 있다. 실제 로, 일부 연구자들은 항산화제를 섭취하면 피부 광노화를 예 방 또는 개선할 수 있을 거라는 기대와 함께 연구를 수행한 결 과 카로텐, 비타민 $\mathrm{E}$ 와 $\mathrm{C}$, 폴리페놀 등이 풍부한 식이를 섭취 하면 자외선에 의해 초래되는 해로운 결과들로부터 보호해주 는 효과가 있었다고 보고하였다(Fernández-Garcia, 2014). Offord et al. (2002)은 $\beta$-카로텐과 라이코펜이 비타민 E와 함께 과산화물의 생성을 막아주었으며 여러 가지 항산화 물 질을 함께 섭취하였을 때 상호작용에 의하여 추가적인 효과를 보였다고 하였다.

본 연구팀은 이전 연구에서 복숭아꽃 에탄올 추출물 $(\mathrm{Et})$ 및 5 가지 분획추출물 $(\mathrm{Hx}, \mathrm{DM}, \mathrm{EA}, \mathrm{Bt}, \mathrm{DW})$ 의 총 폴리페놀 함량 을 측정한 결과 $\mathrm{EA}(394.6 \mathrm{mg}$ tannic acid (TA) eq./g), Bt (128 mg TA eq./g), DM (79.5 mg TA eq./g), Et (78 mg eq./g), DW (16.3 mg TA eq./g), Hx (11.0 mg TA eq./g) 순이었으며,
식물 추출물의 총 폴리페놀 함량과 2,2-diphenyl-1picryl-hydrazyl (DPPH), potassium persulfate 라디칼 및 2,2'-azino-bis(3-ethylbenzothiazoline-6-sulfonic acid) diammonium salt (ABTS) 라디칼을 제거하는 항산 화 효과가 매우 높은 유의한 양의 상관관계가 있었음을 보고 한 바 있다(Kwak \& Choi, 2015). 본 연구에서는 복숭아꽃 추 출물 중 폴리페놀 함량이 높고 항산화 효과가 높았던 상위 4 개 추출물인 $\mathrm{EA}, \mathrm{Bt}, \mathrm{Et}, \mathrm{DM}$ 을 전처리 한 후 $\mathrm{UVB}$ 조사하고 30 $\mathrm{min}$ 후에 ROS 생성에 미치는 영향을 측정한 결과 이들 모두 $\mathrm{ROS}$ 생성을 억제시키는 효과를 보였으나 총 폴리페놀 함량이 높을수록 ROS 생성을 억제하는 효과가 더 크지는 않았다. 따 라서, 이들 추출물이 피부세포에서 UVB 1 회 조사에 의해 유발 되는 급성적 $\mathrm{ROS}$ 생성을 억제시키는 효과는 총 폴리페놀 함량 과 관련성이 있기는 하나 그것만으로 충분히 설명되지는 않는 다. 한편, $\mathrm{UV}$ 를 피부에 1 회 조사하였을 때에는 표피에 존재하 는 항산화 효소들의 발현이나 활성이 감소하고 비효소적인 항 산화 물질들의 농도도 감소되지만, 장기간 반복적으로 조사하 였을 때에는 이들 효소들의 활성이 오히려 증가하였다는 보고 도 있다(Shindo \& Hashimoto, 1995). 피부에 존재하는 항 산화 효소로는 catalase, superoxide dismutase가 대표적 이며 비효소적 항산화 물질로는 glutathione, ascorbic acid, a-tocopherol, ubiquinol 등이 있다(Shindo et al., 1994; Piao et al., 2013).

진피의 구성성분 중 가장 많은 비중을 차지하는 성분은 콜 라겐과 탄력 섬유(elastin)이며 피부 탄력유지에 있어서 중요한 역할을 한다. 조직학적으로 노화된 피부의 진피는 콜라겐 섬유 의 굵기가 감소하고, 배열도 엉성해지며, 탄력섬유의 복잡하고 정교한 결합이 끊어져 있다. 이러한 현상의 주된 원인은 지속적 인 UV 노출에 따른 콜라겐과 탄력섬유 분해효소의 발현증가이 며 이는 노인피부의 주름형성에 가장 주된 원인이 되기도 한다. $\mathrm{UV}$ 는 피부에서 $\mathrm{MMP}$ 의 합성을 증가시켜 콜라겐의 분해를 증가 시키는 동시에 procollagen의 합성을 억제하는 2 가지 경로를 통 하여 collagen matrix를 손상시킨다(Kim \& Chung, 2008).

피부에 있는 $\mathrm{MMP}-1$ 은 콜라겐 1형과 3형을 주로 분해시키 는 효소인데 피부 콜라겐의 80-90\%가 1형이기 때문에 MMPS 중에서 $\mathrm{MMP}-1$ 의 영향력이 실제로는 가장 크다고 볼 수 있다. 한편, 피부세포에서 $\mathrm{MMP}-1$ 의 발현은 미토콘드리아 $\mathrm{DNA}$ 의 손상과 관련성이 있다고 알려졌다. Schroeder et al. (2008)은 $\mathrm{ROS}$ 에 의하여 산화적 스트레스가 증가한 $\mathrm{HDF}$ 세포에서 미토콘 드리아 내의 스트레스 및 DNA 손상으로 인한 미토콘드리아의 기능저하와 함께 MMP-1의 발현이 증가되었다고 보고하였다.

콜라겐 1형은 진피세포에서 콜라겐의 전구체인 procollagen 의 형태로 합성되어 세포외기질로 분비된다고 알려져 있다. 따 라서, MMP-1과 type-1 procollagen 합성에 있어서 적정한 
균형성을 유지하는 것은 피부 세포외기질의 고유성을 유지하 는데 매우 중요하다고 보고되었다(Kim et al., 2015a). 본 연 구에서 4 종의 복숭아꽃 추출물들을 전처리하고 UVB를 조사 한 $\mathrm{HDF}$ 세포에서 MMP-1과 type-1 procollagen의 mRNA 발현에 미치는 영향과 단백질 량에 미치는 영향이 모두 일치하 지는 않았다. 그러나, 복숭아꽃 추출물 중 $\mathrm{EA}$ 와 $\mathrm{Bt}$ 는 공통적 으로 UVB에 의하여 감소되는 type-1 procollagen의 $\mathrm{mRNA}$ 발현 및 단백질 수준을 유의하게 증가시키는 동시에 UVB에 의하여 증가되는 $\mathrm{MMP}-1$ 의 $\mathrm{mRNA}$ 발현과 단백질 수준을 유 의하게 감소시켰기 때문에 UVB에 의해 초래되는 콜라겐의 손 상과 양적 감소를 억제함으로써 피부 광노화를 부분적으로 예 방할 수 있을 것으로 기대된다.

\section{Conclusion}

본 연구결과를 종합해 보면 복숭아꽃 에탄올 추출물인 $\mathrm{Et}$ 와 $\mathrm{DM}, \mathrm{EA}, \mathrm{Bt}$ 분획은 피부세포에서 $\mathrm{UVB}$ 에 의해 유도된 $\mathrm{MMP}-1$ 및 MMP- 3 의 증가를 억제시킴으로써 UVB에 의 해 초래되는 콜라겐 분해를 억제할 것으로 기대되며, 폴리페 놀 함량이 특히 높았던 $\mathrm{EA}$ 와 $\mathrm{Bt}$ 분획은 콜라겐의 전구체인 type-1 procollagen의 합성이 UVB에 의하여 감소되는 것을 억제하는 동시에 콜라겐의 분해효소인 MMPs의 합성은 감소 시킴으로써 UVB로 인한 주름생성을 비롯한 피부광노화를 효 과적으로 예방할 수 있는 기능성 식품이나 화장품 개발을 위 한 천연소재로 이용될 수 있을 것으로 기대된다. 그러나, 앞 으로 복숭아꽃 추출물 $\mathrm{EA}$ 와 $\mathrm{Bt}$ 분획에서 효능물질을 확인하 고 UVB에 의한 피부광노화를 예방하는 분자생물학적인 작용 기전 및 in vivo 시스템에서의 추가적인 연구가 필요하다.

\section{Acknowledgements}

본 논문은 2014년도 미래창조과학부의 재원으로 한국연구재 단의 기초연구사업(NRF-2014R1A2A2A01-007435) 연구비 의 지원으로 수행된 연구결과의 일부이며 이에 감사드립니다.

\section{References}

Baumann L. Skin ageing and its treatment. The Journal of Pathology, 211: 241-251, 2007.

Bradford MM. A rapid and sensitive method for the quantitation of microgram quantities of protein utilizing the principle of protein-dye binding. Analytical Biochemistry, 72: 248-254, 1976.
Chiang HM, Chen HC, Lin TJ, Shih IC, Wen KC. Michelia alba extract attenuates UVB-induced expression of matrix metalloproteinases via MAP kinase pathway in human dermal fibroblasts. Food and Chemical Toxicology, 50: 4260-4269, 2012.

Debacq-Chainiaux F, Leduc C, Verbeke A, Toussaint O. UV, stress and aging. Dermato-Endocrinology, 4: 236-240, 2012.

Fernández-Garcia E. Skin protection against UV light by dietary antioxidants. Food \& Function, 5: 19942003, 2014.

Han W, Xu JD, Wei FX, Zheng YD, Ma JZ, Xu XD, Wei ZG, Wang W, Zhang YC. Prokinetic activity of Prunus persica (L.) batsch flowers extract and its possible mechanism of action in rats. BioMed Research International, 2015: 569853, 2015.

Heo MY, Kim SH, Yang HE, Lee SH, Jo BK, Kim HP. Protection against ultraviolet $\mathrm{B}-$ and $\mathrm{C}$-induced DNA damage and skin carcinogenesis by the flowers of Prunus persica extract. Mutation Research, 496: 4759, 2001.

Hong YF, Lee HY, Jung BJ, Jang SJ, Chung DK, Kim HG. Lipoteichoic acid isolated from Lactobacillus plantarum down-regulates UV-induced MMP1 expression and up-regulates type I procollagen through the inhibition of reactive oxygen species generation. Molecular Immunology, 67: 248-255, 2015.

Hwang ES, Lee DG, Park SH, Oh MS, Kim SY. Coriander leaf extract exerts antioxidant activity and protects against UVB-induced photoaging of skin by regulation of procollagen type I and MMP-1 expression. Journal of Medicinal Food, 17: 985-995, 2014.

Kim JO, Lee CW, Kim EK, Lee SJ, Park NH, Kim HS, Kim HK, Char KH, Jang YP, Kim JW. Inhibition effect of Gynura procumbens extract on UV-B-induced matrix-metalloproteinase expression in human dermal fibroblasts. Journal of Ethnopharmacology, 137: 427-433, 2011.

Kim KB, Jo AR, Cha HJ, Hun SS, Lee JJ, Lee HK, An IS. Synergetic effects of sericin and alpha-mangostin on anti-wrinkle effects. Korean Journal of Aesthetics and Cosmetology, 13: 729-734, 2015b. 
Kim MJ, Woo SW, Kim MS, Park JE, Hwang JK. Anti-photoaging effect of aaptamine in UVBirradiated human dermal fibroblasts and epidermal keratinocytes. Journal of Asian Natural Products Research, 16: 1139-1147, 2014.

Kim MS, Park YG, Lee HJ, Lim SJ, Nho CW. Youngiasides $\mathrm{A}$ and $\mathrm{C}$ isolated from Youngia denticulatum inhibit UVB-induced MMP expression and promote type I procollagen production via repression of MAPK/ $\mathrm{AP}-1 / \mathrm{NF}-\kappa \mathrm{B}$ and activation of $\mathrm{AMPK} / \mathrm{Nrf} 2$ in HaCaT cells and human dermal fibroblasts. Journal of Agricultural and Food Chemistry, 63: 54285438, 2015a.

Kim SM, Chung JH. Berberine prevents UV-induced MMP-1 and reduction of type I procollagen expression in human dermal fibroblasts. Phytomedicine, 15: 749-753, 2008.

Kwak CS, Choi HI. In vitro antioxidant and antiinflammatory activities of ethanol extract and sequential fractions of flowers of Prunus persica in LPS-stimulated RAW 264.7 macrophages. Journal of the Korean Society of Food Science and Nutrition, 44: 1439-1449, 2015.

Lee JY, An BJ. Anti-oxidant and anti-inflammation activities of Prunus persica Flos. Journal of Applied Biological Chemistry, 53: 162-169, 2010.

Lee JY, An BJ. Antioxidant and anti-inflammatory effects of fractions from Pruni persicae Flos. The Korea Journal of Herbology, 27: 55-63, 2012.

Li CM, Wang MH. Antioxidant activity of peach blossom extracts. Journal of the Korean Society for Applied Biological Chemistry, 54: 46-53, 2011.

Liang YC, Huang YT, Tsai SH, Lin-Shiau SY, Chen CF, Lin JK. Suppression of inducible cyclooxygenase and inducible nitric oxide synthase by apigenin and related flavonoids in mouse macrophages. Carcinogenesis, 20: 1945-1952, 1999 .

Mosmann T. Rapid colorimetric assay for cellular growth and survival: application to proliferation and cytotoxicity assays. Journal of Immunological Methods, 65: 55-63, 1983.
Offord EA, Gautier JC, Avanti O, Scaletta C, Runge F, Krämer K, Applegate LA. Photoprotective potential of lycopene, beta-carotene, vitamin E, vitamin C and carnosic acid in UVA-irradiated human skin fibroblasts. Free Radical Biology and Medicine, 32: 1293-1303, 2002.

Piao MJ, Kang KA, Kim KC, Chae SW, Kim GO, Shin TK, Kim HS, Hyun JW. Diphlorethohydroxycarmalol attenuated cell damage against UVB radiation via enhancing antioxidant effects and absorbing UVB ray in human HaCaT keratinocytes. Environmental Toxicology and Pharmacology, 36: 680-688, 2013.

Quan beta, Qin Z, Xia W, Shao Y, Voorhees JJ, Fisher GJ. Matrix-degrading metalloproteinases in photoaging. The Journal of Investigative Dermatology Symposium Proceedings, 14: 20-24, 2009.

Schroeder P, Gremmel T, Berneburg M, Krutmann J. Partial depletion of mitochondrial DNA from human skin fibroblasts induces a gene expression profile reminiscent of photoaged skin. Journal of Investigative Dermatology, 128: 2297-2303, 2008.

Shindo Y, Hashimoto T. Antioxidant defence mechanism of the skin against UV irradiation: study of the role of catalase using acatalasaemia fibroblasts. Archives of Dermatological Research, 287: 747-753, 1995.

Shindo Y, Witt E, Han D, Epstein W, Packer L. Enzymic and non-enzymic antioxidants in epidermis and dermis of human skin. Journal of Investigative Dermatology, 102: 122-124, 1994.

Song JL, Gao Y. Protective effects of Lindera coreana on UVB-induced oxidative stress in human HaCaT keratinocytes. Iranian Journal of Pharmaceutical Research, 13: 1369-1378, 2014.

Yoo HG, Lee BH, Kim WK, Lee JS, Kim GH, Chun OK, Koo SI, Kim DO. Lithospermum erythrorhizon extract protects keratinocytes and fibroblasts against oxidative stress. Journal of Medicinal Food, 17: 1189-1196, 2014. 


\section{국문초록}

\section{인간피부세포에서 복숭이꽃 추출물의 투여가 자외선 B 조사에 의한 활성산소와 Matrix Metalloproteinases 생성 유도를 억제하는 효과}

곽충실*, 양지원

서울대학교 노화고령사회연구소, 서울, 한국

목적: 복숭아꽃 추출물은 항산화 효과와 항염증 효과가 있다고 보고된 바 있다. 본 연구에서는 복숭아꽃 추출물 투여가 인간피부세 포에서 자외선 B 조사에 의한 산화적 스트레스와 matrix metalloproteinase (MMP)의 증가를 억제함으로써 피부 광노화를 예방 할 수 있는지 연구하였다.

방법: 복숭아꽃의 에탄올 추출물(Et)과 그로부터 순차적으로 얻은 디클로로메탄( $\mathrm{DM})$, 에틸아세테이트( $\mathrm{EA})$, 부탄올 $(\mathrm{Bt})$ 분획을 인간 각질형성세포 $(\mathrm{HaCaT})$ 또는 인간 피부섬유아세포 $(\mathrm{HDF})$ 에 전처리하고 자외선 $\mathrm{B}\left(75 \mathrm{~mJ} / \mathrm{cm}^{2}\right)$ 를 조사한 후 활성산소의 생성 은 $\mathrm{DCF}-\mathrm{DA}$ 를 이용하여 측정하였고, $\mathrm{MMP}-1, \mathrm{MMP}-3, \mathrm{MMP}-9$, type-1 procollagen의 mRNA발현과 단백질 합성량은 각각 real-time PCR과 Western blot 방법으로 측정하였다.

결과: $\mathrm{HaCaT}$ 에 복숭아꽃의 $\mathrm{Et}$ 추출물과 $\mathrm{DM}, \mathrm{EA}, \mathrm{Bt}$ 분획을 전처리한 결과 모두 자외선 $\mathrm{B}$ 에 의해 증가한 활성산소와 $\mathrm{MMP}-1$ 의 생성을 유의하게 감소시켰다. 또한, $\mathrm{HDF}$ 에서 $\mathrm{EA}$ 와 $\mathrm{Bt}$ 분획의 전처리는 자외선 $\mathrm{B}$ 를 조사한 대조군에 비하여 $M M P-1, M M P-3$, $M M P-9$ 의 mRNA 발현량과 $\mathrm{MMP}-1$ 과 $\mathrm{MMP}-3$ 합성량을 감소시키는 동시에 type-1 procollagen의 mRNA 발현량과 단백질 합성량은 증가시켰다. 반면, $\mathrm{Et}$ 추출물과 $\mathrm{DM}$ 분획은 $\mathrm{MMP}-1$ 과 $\mathrm{MMP}-3$ 의 합성은 억제시켰으나 type- 1 procollagen의 합성을 증가 시키지는 못하였다.

결론: 복숭아꽃 에탄올 추출물로부터 얻은 $\mathrm{EA}$ 와 $\mathrm{Bt}$ 분획은 피부세포에서 자외선 $\mathrm{B}$ 에 의한 산화적 스트레스와 콜라겐의 분해로부터 보호하는 효과를 보임으로써 식품 또는 화장품 산업에서 자외선 $\mathrm{B}$ 에 의해 초래되는 피부 광노화를 예방하는 기능성 제품 개발을 위한 천연소재로 이용될 수 있다고 판단된다.

핵심어: 복숭아꽃, 활성산소종, Matrix metalloproteinase, Type-1 procollagen, 자외선 B

본 논문은 2014년도 미래창조과학부의 재원으로 한국연구재단의 기초연구사업(NRF-2014R1A2A2A01-007435) 연구비의 지원 으로 수행된 연구결과의 일부이며 이에 감사드립니다.

\section{참고문헌}

김기쁨, 조아령, 차화준, 신상훈, 이정주, 이현경, 안인숙. Sericine과 alpha-Mangostin의 주름개선 상승효과. 대한피부미용학회지, 13: 729-734, 2015.

곽충실, 최혜인. 복숭아꽃 에탄올 추출물과 분획물의 in vitro 항산화 효과 및 RAW 264.7 대식세포에서의 항염증 효과.

한국식품영양과학회지, 44: 1439-1449, 2015.

이진영, 안봉전. 도화(桃花, Prunus persica Flos)의 항산화 및 항염증 활성. 한국응용생명화학회지, 53: 162-169, 2010.

이진영, 안봉전. 도화(桃花, Pruni persicae Flos) 분획물의 항산화 및 항염증 활성. 대한본초학회지, 27: 55-63, 2012. 


\title{
中文摘要
}

\section{人体皮肤细胞中桃花提取物因紫外线照射而诱导的活性氧和 Matrix Metalloproteinases生成抑制效果研究}

\author{
郭忠實 ${ }^{*}$, 楊智媛
}

首尔大學校 老化高齡社會硎究所，首尔，韓國

目的: 有资料显示桃花提取物具有抗氧化及抗炎效果。研究在人体皮肤细胞中桃花提取物抑制紫外线照射而诱导产生的活性氧 和 Matrix Metalloproteinases的生成，从而达到预防皮肤光老化的效果。

方法: 桃花已醇提取物及其不同溶剂萃取相, 即 dichloromethane (DM), ethylacetate (EA) 和n-butanol (Bt) 的萃取物对人体角质 形成细胞(HaCaT)或人皮肤成纤维细胞(HDF)进行预处理之后, 进行紫外线 $\mathrm{B}\left(75 \mathrm{~mJ} / \mathrm{cm}^{2}\right)$ 照射, 然后用DCF-DA测定活性氧的生 成。MMP-1, MMP-3, MMP-9, type-1 procollagen mRNA的表达和蛋白质合成量分别用real-time PCR和 Western blot方法测定。 结果: 桃花已醇提取物及其不同溶剂萃取相 DM、EA、Bt的萃取物对HaCaT进行预处理结果, 因紫外线照射而增加的活性氧和 MMP-1的生成都出现统计意义的减少。在HDF细胞中用EA和 Bt萃取物预处理时, 与紫外线B照射的对照群相比 MMP-1, MMP-3, MMP-9的 mRNA表达和 MMP-1和 MMP-3的合成量减少同时, type-1 procollagen的 mRNA表达和蛋白质合成量却增加了。 除此之外，Et提取物和 DM萃取物抑制 MMP-1和 MMP-3的合成，但未能增加type-1 procollagen的合成。 结论: 从桃花已醇提取物中获得的 $\mathrm{EA}$ 和 Bt萃取物对皮肤细胞因紫外线照射而产生氧化应激和胶原蛋白的分解具有保护效果, 从而确定在食品和化妆品产业中可以作为预防紫外线 $\mathrm{B}$ 引起的皮肤光老化的功效性天然材料。

关键词: 桃花, 活性氧, Matrix metalloproteinase, Type-1 procollagen, 紫外线B 